\title{
動脈壁のリン脂質代謝の研 究*
}

\section{CDP choline: 1, 2-Diacylglycerol Choline- \\ phosphotransferase の性質について—}

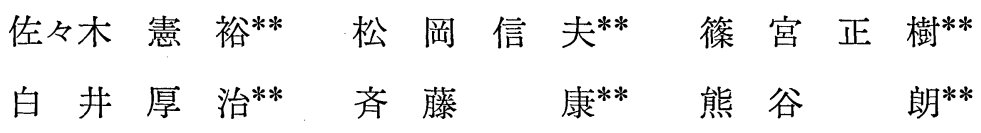

\section{はじめに}

動脈硬化巣に蓄積する脂質は cholesterol ester とリン脂質が多いことが報告されている ${ }^{1,2}$. リン 脂質は生体膜機能保持に重要な役割を果たしてお $り^{2)}$ ，また， lysosome や microsome の脂質代謝 系酵素活性の調節に重大な働きをしていることを 報告してきた ${ }^{3)}$ 。 そこで, 動脈壁内でのリン脂質 代謝と動脈硬化症の病態とのかかわりあいについ て検討を加えた。今回, Phosphatidylcholine の合 成酵素の 1 つである CDP choline: 1,2-Diacylglycerol Cholinephosphotransferase (以下 CPT) の諸 性質，調節因子，および各種病態での活性変動を rat 動脈壁を用いて検討し, rat 肝のそれと比較を 行なったので報告する.

\section{実 験 方法}

酵素液：体重約 $200 \mathrm{~g}$ の wistar 系雄性 rat の大 動脈を起始部から腸骨動脈まで，先に報告した方 法4)により調製し酵素液とした。肝は氷冷生理的 食塩水にて門脈より灌流した後, Teflon/Glass homogenizer で homogenize し $1,000 \mathrm{G}, 15$ 分間の 遠沈後, その上清を酵素液とした. また, 遠心法 により細胞分画を行ない，それぞれの活性を測定 比較した。

CPT 活性の測定 : Golde-Fleischer の方法5) に

* 1978 年 5 月 10 第回日本動脈硬化学会において発表 ** 千葉大学医学部第 2 内科
準じ, Fig. 1 に示すごとく, 反応液は CDP choline (SIGMA ${ }^{\circledR}$ ), CDP choline [methyl- ${ }^{14} \mathrm{C}$ ] (New England Nuclear $\left.{ }^{\circledR}\right)$, 1, 2-diolein (Serdary Research Laboratories ${ }^{\circledR)}$ を用い, 反応停止後, Bligh らの 方法6)で脂質を抽出し, 生成した phosphatidylcholine の放射活性を算出した. 脂質の分離能につい てはTLCを用いて確認した。

\section{結果と考察}

動脈壁 CPT 活性の time course は, ほぼ30分 まで直線的に活性の上昇が見られ, 酵素量でも直 線性が得られた. CDP choline に対する $\mathrm{Km}$ 值は 動脈壁で $0.019 \mathrm{mM}$ ，肝で $0.015 \mathrm{mM}$ であった。 diolein に関しては, 動脈壁で $3.2 \mathrm{mM}$ まで, 肝で $1.6 \mathrm{mM}$ までほぼ直線的に活性の上昇を認めた. 至適 $\mathrm{pH}$ は動脈壁, 肝ともに $\mathrm{pH} 8.5$ に一つの peak を示し，酸性側には活性は認められなかっ た (Fig. 2).ささらに細胞分画法により, 動脈壁 C PT 活性の局在を調べると microsome で最も高い 活性が得られた. $10 \mathrm{mM} \mathrm{MgCl}_{2}$ 存在下での 0.5 $\mathrm{mM}$ divalent cation の動脈壁 CPT 活性への効果 は, $\mathrm{Ca}^{2+}, \mathrm{Zn}^{2+}, \mathrm{Cu}^{2+}, \mathrm{Ba}^{2+}$ でそれぞれ $67 \%$ ， $75 \%, 74 \%, 79 \%$ の抑制, $\mathrm{Mn}^{2+}, \mathrm{Co}^{2+}$ でそれぞれ $120 \%, 31 \%$ の活性の上昇を認めた. 肝でもほぼ同 様であった．高血圧やその他の病態で $\mathrm{Ca}^{2+}$ の動 脈壁への侵入が増加したり, その細胞内局在が変 化したりすることが報告されている7). $\mathrm{Ca}^{2+} に よ$ り著明な活性の低下をきたすことは，動脈硬化症 
動脤硬化 Vol. 6 No. 4 January 1979

Reaction Mixture

( $5 \mathrm{mg} / \mathrm{ml} 1,2$-Diacylglycerol

(final volume $250 \mu \mathrm{l}$ )

(ultrasonificated with $0.1 \mathrm{M}$ Tris $\cdot \mathrm{HCl}$ -

$0.03 \%$ Tween 20 )

2mM CDP choline

$4 \mu \mathrm{Ci} / \mathrm{m} l\left[{ }^{14} \mathrm{C}\right]-\mathrm{CDP}$ choline

$0.1 \mathrm{M} \mathrm{MgCl} 2$

$0.1 \mathrm{M}$ Glutathione

$0.1 \mathrm{M}$ Tris $\cdot \mathrm{HCl}-0.03 \%$ Tween $20(\mathrm{pH} 8.5)$

$\downarrow$ Enzyme Solution

Incubation $37.0^{\circ} \mathrm{C}, \quad 20 \mathrm{~min}$.

$\downarrow$

Termination of Reaction with $2 \mathrm{~m} l$ of Chloroform Methanol $(1: 2, \mathrm{v} / \mathrm{v})$

Lipid Extraction by Method of Bligh \& Dyer $\downarrow$

Washing of Lower Phase with $2 \mathrm{ml}$ of

Methanol-Water (1: 1, v/v), twice<smiles>[AlH2]</smiles>

Counting of Radioactivity in $0.4 \mathrm{~m} l$ of Lower Phase

Fig. 1 Assay procedure of CDPcholine: DG cholinephosphotransferase.

の risk factor の作用機構としての $\mathrm{Ca}^{2+}$ の果す役 割が重要であることが推測される.以上より動脈 壁および肝の本酵素は，その細胞内局在やその性 質に著明な差異は認めなかった. 動脈壁 CPT 活 性は, GEDTA 処理血清を添加すると, 低濃度血 清で $43 \%$ の活性の上昇を認めた。 このことは血清

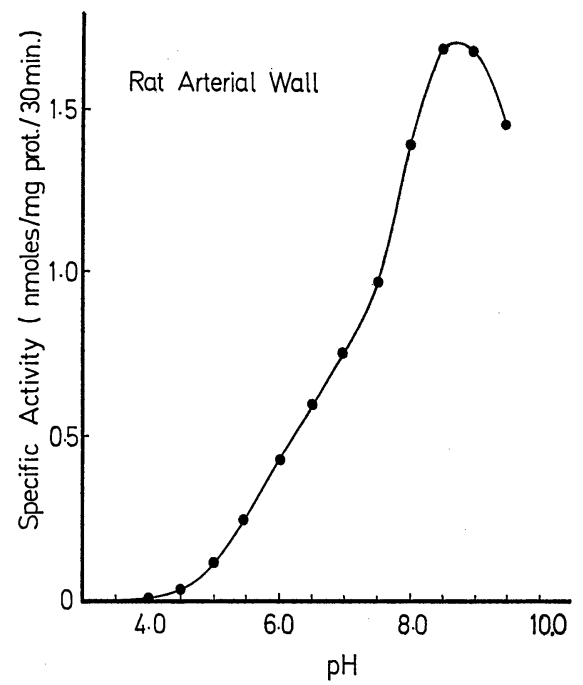

$20 \mu l$ $25 \mu l$ $10 \mu l$ $85 \mu l$ $50 \mu l$
に CPT 活性を調節する因子が存在することを示 している.ささらに血清成分の 1 つであるリポ蛋白 の動脈壁 CPT 活性への効果では, 超低比重リポ 蛋白 (VLDL), 低比重リポ蛋白 (LDL) は低濃度 で，それぞれ最高 $14 \% ， 38 \%$ の活性の上昇を認め たが，高比重りポ蛋白 (HDL) は濃度依存性に抑 制を示した (Fig. 3). 動脈硬化巣ではリン脂質の 合成が立進することが報告されている ${ }^{8,9)}$. LDL が血管壁に侵入し cholesterol を蓄積すると同時

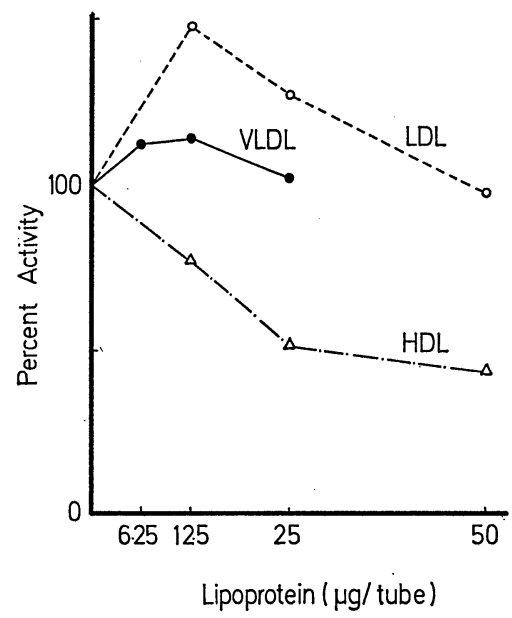

Fig. 3 Effect of Lipoproteins on CDPcholine:DG Cholinephosphotransferase Activity in Rat Arterial Wall

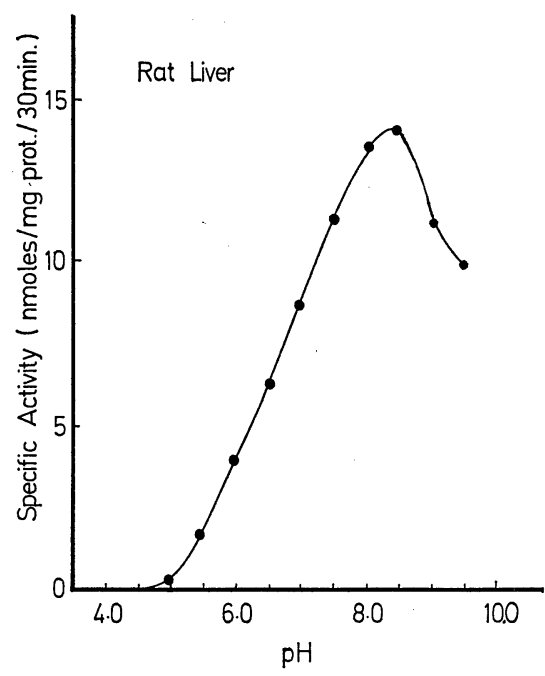

Fig. 2 Effect of pH on CDPcholine: DG Cholinephosphotransferase Activity in Rat Arterial Wall and Liver. 
に, CPT 活性を誘導し Phosphatidylcholine の合 成を促進する可能性を示しており，いかなる機構 によるのかさらに検討を加えねばならない，種々 の病態での本酵素活性の変動は Fig. 4 に示すよ 5に, 高 cholesterol 負荷食 $(1 \%$ コレステロール， $0.5 \%$ コール酸含有 16 週間投与), Vitamin E 欠乏食 (16週間)では活性の上昇を，加齢 (4週齢に対し50 週齢), 自然発症高血圧 $\operatorname{rat}(\mathrm{SHR})$ では活性の低下 を示した. これらは動脈硬化症の risk factor とし てよく知られているものであるが，それらが動脈 硬化症にいかなる機構で関与しているのか，また， CPT 活性の調節機序および病態との関連につい て検討を重ねていきたい.

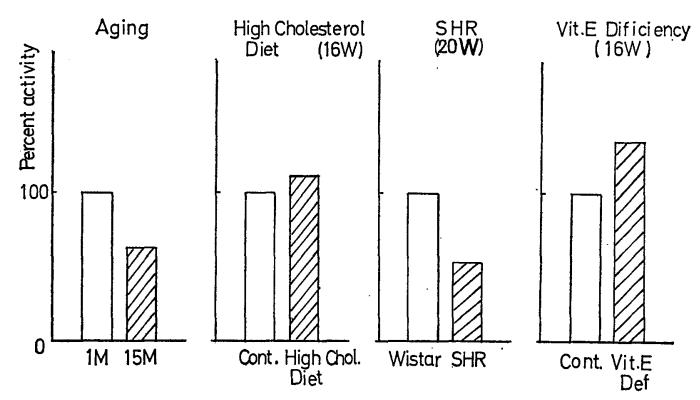

Fig. 4 CDP choline: DG Cholinephosphotransferase Activity in Rat Arterial Wall in Various Phathological States.

\section{文献}

1) Getz, G. S., Vesselinovitch, D. and Wissler, R. W.: A Dynamic Pathology of Atherosclerosis. Am. J. Med., 46: 657-673 (1969).

2) Jackson, R. L. and Gotto, A. M.: Phospholipids in Biology and Medicine (Second of Two Parts). N. Engl. J. Med., 290: 87-93 (1974).

3) 篠宮正樹, 松岡信夫, 白井厚治, 森崎信尋, 村野俊 一, 佐々木憲裕, 斎藤 康, 熊谷 朗, 奥田拓道： 動脈壁 Cholesterol esterase とリポ蛋白. 日本臨床 代謝学会記録, 15: (1978) 印刷中

4) 松岡信夫, 篠宮正樹, 白井厚治, 森崎信尋, 村野俊 一, 佐々木憲裕, 斎藤 康, 熊谷 朗：高コレステ ロール血症と動脈壁脂質代謝. 6: 121-127 (1978).

5) Golde, L. M. G. V., Fleischer, B. and Fleischer, S.: Some Studies on The Metabolism of Phospholipids in Golgi Complex from Bovine and Rat Liver in Comparison to Other Subcellular Fractions. Biochim. Biophys. Acta., 249: 318-330 (1971).

6) Bligh, E. G. and Dyer, W. J.: A Rapid Method of Total Lipid Extraction and Purification. Can. Biochem. Physiol., 37: 912-917 (1959).

7) Baudouin, M., Meyer, P., Fermandjian, S. and Morgat, J.: Calcium Release induced by Interaction of Antiotensin with its Receptors in Smooth Muscle Cell Microsomes. Nature, 235: 336-338 (1972).

8) Newman, H. A. I., Day, A. J. and Zilversmit, D. B.: In Vitro Phospholipid Synthesis in Normal and Atheromatous Rabbit Aortas. Circ. Res., 19: 132138 (1966).

9) Portman, O. W. and Alexander, M.: Metabolism of sphingolipids by normal and atherosclerotic aorta of squirrel monkeys. J. Lipid. Res., 11: 23-30 (1970).

\section{質問 高野達哉（帝京大）}

G6 Pase は動脈壁にはないと考えられています が，いかでしょらか. G6Pase を用いて phosphatase を測定している可能性は考えられませんか。

\section{回答 斉藤康}

nonspecific phosphatase との異同に関する検討 を加える必要があると思いますが, Brecher も rabbit 動脈壁でその存在を報告しています. 種差 などについても検討したいと思います.

\section{質問 秦搌哉 (慶応大内科)}

動脈壁のリン脂質合成系のうち， cholinephosphotransferase を測定していますが，他酵素との 比較はなさったでしょうか.

\section{回答 斎藤康}

cholinephosphotransferase は基質として Diacylglycerol を利用しますが, Diacylglycerol は Triacylglycerol, phosphatidate, phosphatidylethanolamine の合成にも利用され, 各反応の分岐部と もいえる位置にあり, 各脂質代謝比較の上で重要 と考えられますので, 今回数経路ある phosphatidylcholine の合成反応のうち, 本酵素反応を選び ました. どの反応経路が幹線であるのかの確認は 他のリン脂質の合成反応とともに, 今後検討して いく予定です。

\section{質問 野間昭夫 (都立養育院内科)}

LDL, VLDL および HDL の酵素活性に対する 


\section{動脈硬化 Vol. 6 No. 4 January 1979}

作用は，リン脂質（特にレシチン）の量より考え てはいかがでしょらか.この酵素は逆反応も起こ ることがわかっているのでこの点は問題になると 思いますが。

\section{回答 佐々木憲裕}

本酵素反応の可逆反応，あるいはリポ蛋白中の phosphatidylcholine による substrate inhibition は
考え得ますが，低濃度の血清やリポ蛋白にて，む しろ活性の上昇が見られたことは， substrate inhibition とは異なった機構と思われ，血清，リポ 蛋白に本酵素の活性を上昇させる因子が存在して いると推測されます，現在アポ蛋白の効果につい て検討中です. 


\title{
Summary
}

\section{Study on Phospholipid Metabolism in Rat Arterial Wall (1) -CDP Choline: 1, 2-Diacylglycerol Cholinephosphotransferase-}

\author{
Norihiro Sasaki, Nobuo Matsuoka, Masaki Shinomiya, Kohji ShIRAI, \\ Yasushi SaIto and Akira KumagaI
}

The Second Department of Internal Medicine, School of Medicine, Chiba University

It has been reported by many investigators that phospholipids are markedly increased in atherosclerotic lesions as well as cholesterylesters. We studied the characteristics of, and the mechanisms of regulation of CDP choline: 1,2-diacylglycerol cholinephosphotransferase (CPT) activity, one of the enzymes which synthesize phosphatidylcholine, in rat arterial wall comparing with those in rat liver.

CPT activity showed a linear relationship with incubation time and concentration of enzyme protein, upto 30 minutes and $0.1 \mathrm{mg}$ of protein per tube, respectively. Apparent $\mathrm{Km}$ value for $\mathrm{CDP}$ choline was $0.019 \mathrm{mM}$ in aorta and $0.015 \mathrm{mM}$ in liver. A linear activation of the enzyme was observed with upto $3.2 \mathrm{mM}$ of diolein in aorta and $1.6 \mathrm{mM}$ in liver. A maximum activity was observed around $\mathrm{pH} 8.5$ in both in aorta and liver. In subcellular fractionaton of aorta, the highest specific activity per protein content was located in microsomal fraction.

When $\mathrm{Ca}^{2+}, \mathrm{Zn}^{2+}, \mathrm{Cu}^{2+}$ and $\mathrm{Ba}^{2+}$ were added, CPT activity was remarkably inhibited, but $\mathrm{Mn}^{2+}$ and $\mathrm{Co}^{2+}$ increased the activity in aorta in the presence of $\mathrm{Mg}^{2+}$.

CPT activity was increased by addition of a low concentration of serum. Very low density lipoprotein (VLDL) and low density lipoprotein (LDL) activated CPT activity, though high density lipoprotein (HDL) inhibited the activity. This may imply that LDL induced CPT activity in arterial wall, directly or indirectly.

CPT activity was also compared in various pathological states. Higher activity was found in hypercholesterolemic and vitamin $\mathrm{E}$ deficient rats than the controls. Fifty week-old rats showed significantly lower CPT activity in aorta than 4 weekolds. In spontaneous hypertansive rats, CPT activity was significantly lower in Wistar-King strain rats.

Further investigations are required in order to clarify the mechanism of regulation of CPT activity in arterial wall from the point of view of various pathological states of arterial wall.

Key words: CDP choline: 1,2-diacylglycerol cholinephosphotransferase (CPT), arterial wall, LDL, HDL, spontaneous hypertensive rats 